Finally, it may be of interest to note that the ratio of complement-fixation to haemagglutination-inhibition or neutralization titres seemed to remain stable over the eight-month period studied, unlike what has been reported after natural measles (Stokes et al., 1961), or after immunization with live vaccine (Stokes et al., 1962), in which cases a drop in complementfixation titres relative to neutralization titres were observed. Whether or not this apparent difference is significant will be elucidated by further follow-up studies.

\section{Summary}

A group of children vaccinated with three monthly doses of a formalin-killed vaccine at the age of $\frac{1}{2}$ to 2 years were (a) submitted to clinical and serological follow-up analyses 22 to 23 months after vaccination, (b) given a fourth dose of either formalin-killed vaccine or purified haemagglutinin prepared from Tween-ether-treated material, and (c) followed during an additional period of eight months.

In addition to the previously reported four cases of mainly mild measles among 15 children exposed to natural measles two more cases appeared among five children exposed during 22 to 23 months after vaccination. One case was associated with pneumonia of doubtful aetiology, and one was a mild case with slight fever and a faint rash.

In 25 out of 26 children ( $96 \%$ ) haemagglutination-inhibition antibodies in a titre $>10$ were detectable 22 to 23 months after vaccination, and there was a twofold decrease in titre since the nearest previous follow-up analysis, 14 months earlier.

Two to four weeks after revaccination the geometric mean haemagglutination-inhibition titre of the group of 14 children given formalin-killed vaccine had increased 35 times, whereas the corresponding figure for a group of 14 children given Tween-ether vaccine was 100 . There was a good correlation with neutralizing and complement-fixation titres. Six weeks later the mean haemagglutination-inhibition titre had been reduced 5.5-fold in the formalin-killed group and 2.4-fold in the Tween-ether group. No further reduction in titres could be detected during the next six months. The mean haemagglutination-inhibition titre eight months after revaccination was 600 in the group of children given formalin-killed vaccine, and 7,800 in the group given Tween-ether vaccine.

The excellent technical assistance of Miss Ulla Arfwidsson, Miss Birgitta Norén, Miss Britt Akestad, and Miss Britt-Marie Andersson is gratefully acknowledged.

\section{REFERENCES}

Carter, C. H., Conway, T. J., Cornfeld, D., Iezzoni, D. G., Kempe, C. H., Moscovici, C., Rauh, L. W., Vignec, A. J., and W'arren, J. (1962). 7. Amer. med. Ass., 179, 848.

Feldman, H. A., Novack, A., and Warren, J. (1962). Ibid., 179, 391. Fulginiti, V. A., and Kempe, C. H. (1963). Amer. F. Dis. Child., 106, 450 .

Guinee, V. F., et al. (1963). Amer. F. publ. Hlth, 53, 645.

Janeway, C. A., and Gitlin, D. (1957). Advanc. Pediat., 9, 65. Karelitz, S., Berliner, B. C., Orange, M., Penbharkkul, S., Ramos, A., and Muenboon, P. (1963). 7. Amer. med. Ass., 184, 673. arch. Virusforsch., 13, 548 .

- (1965). Acta paediat. (Uppsala). In press. artin, C. M., Manfredonia, S. J., Webb, N. C., jun., Markham, F. S., and Ruegsegger, J. M. (1963). Amer. F. Dis. Child., 106, 267. Reilly, C. M., Buynak, E. B., and Hilleman, M. R. (1961). Amer. 7. Hyg., 74, 293.

Medoff, H. S., Hunt, A. R., Karpinski, F. E., Salitsky, S., and Wheeler, J. E. W. (1964). \%. Amer. med. Ass., 189, 723.

Carlström, Gun, Lagercrantz, R., and Gard, S. (1964). Acto paediat. (Uppsala), 53, 533.

Norrby, E. (1964). Studies on Measles Virus: Habilitation Thesis. Balder, Stockholm.

Peck, F. B., jun. (1965). Arch. ges. Virusforsch., 16, 327.

Peck, F. B., jun. (1965). Arch. ges. Virusforsch., 16, 327. Stokes, J., jun., Hilleman, M. R., We. F. Med., 267, 222.

W.H.O. (1963). Techn. Rep. Ser., No. 263.
In 1954 Enders and Peebles reported the isolation of measles virus in human and monkey kidney cell cultures. The first strain to be isolated was from a boy named Edmonston and was attenuated by serial passage in human amnion cultures and whole chick embryos (Milovanović et al., 1957) and finally serially propagated in chick embryo fibroblast cultures (Katz et al., 1958). The attenuated strain (Enders-Edmonston) no longer gave clinical signs of the disease when inoculated into monkeys (Enders et al., 1960). Live vaccine prepared from it was tried in children (Katz and Enders, 1959 ; Krugman et al., 1962), and although it gave good measles antibody responses it caused febrile reactions with rash in more than half the children. Such reactions were greatly reduced by giving a simultaneous dose of gamma-globulin (Stokes et al:, 1961).

In order to obtain a vaccine free from reactions there are two possibilities. Either the virus may be further attenuated for use in a live vaccine or an inactivated vaccine may be prepared, and both possibilities have been investigated. In the U.S.A. Schwarz (1962) further attenuated the EndersEdmonston strain by passage in chick embryo fibroblast cultures, and live vaccine produced from it gave good antibody titres in children without causing the comparatively severe reactions which occurred after vaccine from the original strain (Krugman et al., 1963 ; Andelman et al., 1963). A similar further-attenuated strain (Goffe strain) has also been produced in this country from the Enders-Edmonston strain, and live vaccine prepared from this was also shown to give good antibody responses' with fewer reactions than the original strain (Hendrickse et al., 1964 ; Benson et al., 1964). Inactivated vaccine has been prepared by Warren and Gallian (1962) by inactivating the Enders-Edmonston strain with formaldehyde

\footnotetext{
* Professor Wilson Smith (chairman), Professor D. G. Evans, Professor W. Gaisford, Professor C. H. Stuart Harris, Dr. J. Stevenson Logan Dr. K. McCarthy, Dr. C. L. Miller, Professor Sir Alan Moncrieff Dr. K. McCarthy, Dr. C. L. MiTher, Professor. G. I. Watson, Sir Dr. Ian Sutherland, Dr. D. Thomson, Dr. G.

Graham Wilson, and Dr. F. T. Perkins (secretary). The trials were co-ordinated by Dr. C. L. Miller, of the M.R.C.
Laboratories, and the serological tests were done by Dr. M. Clarke, of the M.R.C. Division of Immunological Products Control. The results were analysed by Miss N. Seyd, of the M.R.C. Statistical Research Unit.

The report was prepared by Dr. Ian Sutherland, Dr. F. T Perkins, and Professor D. G. Evans.
} 
and adsorbing it on aluminium hydroxide gel. It was found that although antibody was induced in children after three doses of vaccine it was sometimes no longer detectable after six months (Carter et al., 1962). A combined schedule, however, in which inactivated vaccine was followed by live EndersEdmonston vaccine caused very few reactions and the antibody titres were of the same order as those produced by live vaccine alone (Guinee et al., 1963 ; Fulginiti et al., 1963).

Apart from the ability of measles vaccine to produce $a{ }^{\prime} " \cdots$ responses in children, trials have also shown that the accines are able to protect against the disease at least for $t_{\perp} e$ four-year period for which they have so far been investigated (Krugman et al., 1965).

In the first quarter of 1964 trials of measles vaccines were made in Britain under the auspices of the Medical Research Council's Measles Vaccines Committee. These trials stemmed from the recognition 'hat measles, although an unimportant incident for the $\cdot$, urity of children, may sometimes be dangerous and casionally have neurological complications (Miller, 1964). In addition, measles epidemics cause much extra work for general practitioners and the cost of antibintic treatment for upper respiratory complications must also be con. Sered. $\therefore \therefore . . . \mathrm{cr}$, as indicated above, measles vaccines

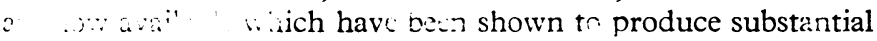

..ses in non-immune clitildren as wit as ...i.un ajunst the disease.

\section{General Plan}

The serological responses and post-vaccination reactions to four vaccination schedules were studied in non-immune children aged about 10 to 18 months; no attempt was made to assess the degree of protection against a subsequent attack of measles. The four vaccination schedules, consisting of a single injection of one of two live attenuated vaccines with or without a preceding single injection of an inactivated vaccine, were as follows:

Schedule A.-One subcutaneous injection of $0.5 \mathrm{ml}$. of live vaccine A prepared from the Goffe strain by Wellcome Laboratories, Batch $M V / 20 / 1$.

Schedule B.-One subcutaneous injection of $0.5 \mathrm{ml}$. of live vaccine $B$ prepared from the Schwarz strain by Glaxo Laboratories, Batch 18 .

Schedule KA.-One intramuscular injection of $1 \mathrm{ml}$. of inactivated vaccine $K$ prepared by Pfizer Ltd. from the Enders-Edmonston strain, Batch 6, followed at an interval of four to six weeks by one subcutaneous injection of $0.5 \mathrm{ml}$. of the Wellcome live vaccine A.

Schedule KB.-One intramuscular injection of $1 \mathrm{ml}$. of the Pfizer inactivated vaccine $K$ followed at an interval of four to six weeks by one subcutaneous injection of $0.5 \mathrm{ml}$. of the Glaxo live vaccine $\mathrm{B}$.

To obtain an adequate number of children, two separate groups were included, one being recruited by general practitioners and the other consisting of children attending the London County Council day nurseries. The parents were approached and in each case agreed to the participation of their children. There were certain differences in procedure in the two studies, and they are therefore described separately.

Two blood samples were taken from each vaccination child -one shortly before vaccination was begun and the other four to six weeks after giving the live vaccine.

\section{General-practitioners Study}

General practitioners were invited to undertake this study through the Epidemic Observation Unit of the College of General Practitioners. They sought the co-operation of mothers of susceptible children in the appropriate age-group, took the required blood samples, vaccinated the children, and supervised the required recording of temperatures and symptoms by the mother. A total of 38 practitioners co-operated and 242 children were included in the study. The children, who had no history of measles or of contact with the disease at home, were allocated to one of the four vaccination schedules from prearranged lists based on random sampling numbers. The key to the allocations to the various schedules was held confidentially at the M.R.C. Laboratories. The vaccines were issued as required and, on receipt by the practitioner, they were stored at $2-10^{\circ} \mathrm{C}$., the live vaccine being used within 14 days of issue.

The mother was instructed to take an early evening rectal temperature of each vaccinated child on the day the live vaccine was given and on each of the following 14 days. She was also asked to note on each day during this period the presence or absence of malaise, loss of appetite, headache, disturbed sleep, blocked nose, running eyes, cough, sore throat, earache, bowel upset, rash, or the occurrence of other unusual symptoms. In addition, in order to obtain comparative information from unvaccinated children, one child in five was selected at random for a similar 15-day period of observation to be completed before starting the allocated vaccination schedule. These children, on completing their vaccination schedule, were thus due for a second 15-day period of observation. Further, as a check on intercurrent infections in the family which might by affecting the vaccinated child simulate a vaccination reaction, the next older sibling (if any) of each vaccinated child was observed by the mother in the same way, except that oral rather than rectal temperatures were taken for the same period or periods.

\section{Day-nurseries Study}

With the co-operation of the Chief Medical Officer of the London County Council, the trial was extended to a number of day nurseries in London. The nurseries were visited by an M.R.C. vaccination team, who offered vaccination to susceptible children in the appropriate age-group, took the required blood samples, and vaccinated the children. Temperatures and symptoms following the vaccination were recorded by the daynursery staff. A total of 20 day nurseries took part in the trial and 108 children were included.

The principal difference between the investigation in the day nurseries and that in the general practice concerned the information on post-vaccination reactions. This information was collected from the seventh to the tenth days after the dose of live vaccine, since experience had shown that any clinical reactions to vaccination would occur in this period and because it fitted conveniently with the arrangements for the day-nurseries staff to make the observations. A further point of difference was the lack of comparative information for unvaccinated daynursery children. It was arranged instead that those allocated to the two-dose schedules should be observed from the seventh to the tenth days after the dose of killed vaccine as well as after that of live vaccine. It was not expected that the killed vaccine would give rise to any untoward reactions during the observation period, and thus the observations after the dose of killed vaccine provided an acceptable comparison with the observations after the dose of live vaccine. No observations were made on older siblings of the vaccinated day-nursery children.

\section{Post-vaccination Reactions in the General-practitioners Study}

The post-vaccination reactions in the general-practitioners study were examined in some detail to ascertain their timing and nature and to enable a simplified presentation to be made of the findings in the day-nurseries study and in both parts of the investigation combined. 


\section{Number of Subjects}

Of the total of 242 children allocated, 40 (9A, 10B, 10KA, $11 \mathrm{~KB}$ ) had to be excluded from the trial. Of these, four were found to have a pre-vaccination antibody titre of 0.25 unit or more, indicative of a previous attack of measles, six were found to have a history of contact with the disease at home, one was more than 2 years old, four did not complete their vaccination schedule because of illness or another immunization, four moved away from the district, and the parents of 21 either withdrew or failed to return any record of temperature and symptoms. There remained 56 children on schedule $A, 56$ on schedule B, 44 on schedule $\mathrm{KA}$, and 46 on schedule $\mathrm{KB}$. As will be seen from the Tables a few of these children were excluded from the final analysis, since for various reasons complete records were not obtained. Observations were made on 25 of the participants before they were vaccinated and corresponding data are also available for 120 older siblings of the vaccinated children (59\%).

Of the 202 children on the four different schedules, 101 were boys and 101 were girls; nine were aged 9 months or less (including one aged 5 months) and 30 had reached an age of 19 months or more (including six aged 22 months) by the time they were given the live vaccine. These children have been retained in the study even though they fell outside the originally intended age-range of 10 to 18 months.

\section{Evening Temperature}

In $30 \%$ of the children the mother took axillary and not rectal temperatures. To convert these to an approximation of the rectal temperatures, $1^{\circ} \mathrm{F}$. $\left(0.55^{\circ}\right.$ C. $)$ was added to each axillary reading. An analysis of the two sets of readings showed this to be an appropriate correction, and the work of Moncrieff and Hussey (1948) supports this. In the analysis below, a child has been regarded as having a raised temperature on a given day if the early evening rectal temperature (or its equivalent) was $100^{\circ} \mathrm{F}$. $\left(37.8^{\circ}\right.$ C.) or more.

The number of children showing a raised temperature daily from the fifth to the tenth days after vaccination (with daily averages for the previous and subsequent periods) is shown in Table I. Of the 54 children observed with complete records following schedule $\mathrm{A}, 12 \%$, on average, showed raised temperatures each day during the first four days after vaccination and a similar percentage from day 11 onwards. In the intervening period, however, the percentage rose to $44 \%$ on day $7,50 \%$ on day 8 , and $39 \%$ on day 9 , indicating that a substantial proportion of these children must have had an unusual temperature rise during this time. A similar pattern was shown by the 49 children observed with complete records following schedule B. Here the percentages with a raised temperature increased from an average of $17 \%$ during the first four days to $29 \%$ on day $7,41 \%$ on day 8 , and $43 \%$ on day 9 . With the $\mathrm{KA}$ and $\mathrm{KB}$ schedules there was no evidence of any unusual temperature changes nor was there in the observations on the unvaccinated group. It may be concluded that a single injection of either of the live vaccines led to temperature rises in a substantial proportion of the children between five and ten days after vaccination, centred on about the eighth day. If, however, the live vaccine was preceded by a single dose of the killed vaccine such rises of temperature apparently did not occur.

The timing and extent of these temperature changes were studied more closely. For many of the children in each of the vaccination schedules, as well as for those in the unvaccinated group, the highest recorded temperature was often under $101^{\circ}$ F. $\left(38.3^{\circ}\right.$ C.), and such small temperature rises occurred uniformly throughout the observation period; they are therefore likely to have been due to causes other than vaccination. Higher temperatures were recorded less frequently ; their distribution was reasonably uniform throughout the period for schedules $\mathrm{KA}$ and $\mathrm{KB}$, as well as in the unvaccinated group (suggesting no relation to the vaccination), but after a single dose of live vaccine $A$ or $B$ temperatures of $103^{\circ} \mathrm{F} .\left(39.4^{\circ} \mathrm{C}\right.$.) or more were particularly noticeable between the seventh and tenth days. It may be concluded that most of the temperatures between 101 and $103^{\circ} \mathrm{F}$. (38.3 and $39.4^{\circ}$ C.) or more, occurring in the period seven to ten days after a single dose of either live vaccine, were caused by the vaccine. On the other hand, few or none of the temperatures of $101^{\circ} \mathrm{F}$. ( $38.3^{\circ}$ C.) (or more) seven to ten days after the $\mathrm{KA}$ or $\mathrm{KB}$ schedule appear to have been due to the vaccination.

\section{General Symptoms}

Any report of malaise, loss of appetite, headache, or disturbed sleep on a given day was regarded as evidence of some generalized upset in the child on that day. An analysis (analogous to that of Table I) was made of the numbers of children with one or more of these general symptoms on each day of the 15-day observation period. The numbers showed a definite increase during the seventh to eleventh days after schedules $A$ and $B$, but not after schedules $K A$ or $K B$ or in the unvaccinated group. It may be concluded that the live vaccines given alone led to some generalized upsets, centred on about the ninth day after vaccination. These upsets, like the temperature changes, apparently did not occur if the live vaccine was preceded by the killed vaccine.

\section{Rash}

The mother was asked to note any skin rash, and a small number of children, usually one or two in each vaccination schedule, had a rash of some kind (such as a napkin rash) on each day of observation; there were similar findings in the unvaccinated group. Among the 56 children given vaccine $A$ alone, however, some rashes were associated with a temperature of $101^{\circ} \mathrm{F}$. $\left(38.3^{\circ} \mathrm{C}\right.$.) or more ; one such rash started on day 7 , two on day 8 , six on day 9 , three on day 10 , and two on day 11 . The occurrence of rash in the other three schedules was not significantly different from that of the control group.

\section{Upper Respiratory Symptoms}

Any report of blocked nose, running eyes, cough, sore throat, or earache on a given day was regarded as evidence of some

TABLE I.-Number of Children with Evening Temperatures of $100^{\circ} \mathrm{F} .\left(37.8^{\circ} \mathrm{C}\right.$.) or Over: General-practitioners Study

\begin{tabular}{|c|c|c|c|c|c|c|c|c|c|c|c|c|c|c|c|c|c|}
\hline \multirow{3}{*}{$\begin{array}{l}\text { Vaccination } \\
\text { Schedule }\end{array}$} & \multirow{3}{*}{$\begin{array}{l}\text { No. of Children with } \\
\text { Complete Records }\end{array}$} & \multicolumn{16}{|c|}{ Days after Vaccination } \\
\hline & & \multicolumn{2}{|c|}{$\begin{array}{c}\text { Mean Over } \\
\text { Days 1-4 } \\
\end{array}$} & \multicolumn{2}{|c|}{5} & \multicolumn{2}{|c|}{6} & \multicolumn{2}{|c|}{7} & \multicolumn{2}{|c|}{8} & \multicolumn{2}{|c|}{9} & \multicolumn{2}{|c|}{10} & \multicolumn{2}{|c|}{$\begin{array}{l}\text { Mean Over } \\
\text { Days 11-13 } \\
\end{array}$} \\
\hline & & No. & $\%$ & No. & $\%$ & No. & $\%$ & No. & $\%$ & No. & $\%$ & No. & $\%$ & No. & $\%$ & No. & $\%$ \\
\hline $\begin{array}{c}\stackrel{\mathrm{B}}{\mathrm{B}}_{\mathrm{K} \mathbf{\mathrm { K }}} \\
\mathbf{K B} \\
\text { Control (no vaccine) }\end{array}$ & $\begin{array}{l}54 \\
49 \\
35 \\
37 \\
25\end{array}$ & $\begin{array}{l}6 \cdot 5 \\
8 \cdot 2 \\
6 \cdot 0 \\
6 \cdot 8 \\
3 \cdot 5\end{array}$ & $\begin{array}{l}12 \\
17 \\
17 \\
18 \\
14\end{array}$ & $\begin{array}{r}13 \\
12 \\
5 \\
6 \\
2\end{array}$ & $\begin{array}{r}24 \\
24 \\
14 \\
16 \\
8\end{array}$ & $\begin{array}{r}16 \\
10 \\
6 \\
5 \\
3\end{array}$ & $\begin{array}{l}30 \\
20 \\
17 \\
14 \\
12\end{array}$ & $\begin{array}{r}24 \\
14 \\
7 \\
5 \\
1\end{array}$ & $\begin{array}{r}44 \\
29 \\
20 \\
14 \\
4\end{array}$ & $\begin{array}{r}27 \\
20 \\
5 \\
5 \\
1\end{array}$ & $\begin{array}{r}50 \\
41 \\
14 \\
14 \\
4\end{array}$ & $\begin{array}{r}21 \\
21 \\
7 \\
3 \\
3\end{array}$ & $\begin{array}{r}39 \\
43 \\
20 \\
8 \\
12\end{array}$ & $\begin{array}{r}13 \\
12 \\
9 \\
3 \\
2\end{array}$ & $\begin{array}{r}24 \\
24 \\
26 \\
8 \\
8\end{array}$ & $\begin{array}{l}6 \cdot 3 \\
5 \cdot 3 \\
6 \cdot 0 \\
3.0 \\
2 \cdot 3\end{array}$ & $\begin{array}{r}12 \\
11 \\
17 \\
8 \\
9\end{array}$ \\
\hline
\end{tabular}


upper respiratory disturbance in the child on that day. An analysis (analogous to that of Table I) was made of the numbers of children with one or more of these symptoms on each day of the 15-day observation period. This showed some excess of children with upper respiratory symptoms from day 7 to day 10 following vaccination schedules $A$ and $B$, but not after schedules $\mathrm{KA}$ or $\mathrm{KB}$.

\section{General Assessment of Disturbance in the Child}

Twelve children had troublesome upsets of which only four (3 A, 1 B) occurred predominantly or entirely during the period seven to ten days after vaccination. No child suffered any reaction that could be regarded as clinically serious after any of the vaccination schedules.

\section{Observations on Siblings}

The corresponding observations on temperature and symptoms in the 120 older siblings of the 202 vaccination children were also analysed in some detail. These observations are of less value as "control" information than those on the study children themselves, because they necessarily relate only to those study children who had siblings. The highest recorded temperatures and the frequency of malaise, rash, and upper respiratory symptoms were tabulated for days 3 to 6 and days 7 to 10 for each vaccination schedule separately after giving vaccine to the children in the study. With the unvaccinated siblings of children on schedules $\mathrm{B}, \mathrm{KA}$, and $\mathrm{KB}$ there were no notable differences in temperatures or frequencies of the various symptoms between days 3 to 6 and days 7 to 10 after vaccination of the study child, or between the three schedules. There was, however, an unusually high prevalence of upper respiratory symptoms among siblings of children on schedule A seven to ten days after vaccination. It would thus appear that the excess of study children with upper respiratory symptoms seven to ten days after schedule A might possibly have been due to intercurrent infection in the family and not necessarily to the vaccination.

\section{Post-vaccination Reactions in the Day-nurseries Study}

It will be clear from the foregoing sections that temperature rises and symptoms can be attributed to the vaccination when they develop during the period seven to ten days after the dose of live vaccine. In assessing the frequency of post-vaccination reactions in the day-nurseries trial, therefore, it was decided to consider only temperature rises and symptoms recorded during this short period of observation.

Number of Subjects.-Of the total of 108 children allocated in the day nurseries, $11(1 \mathrm{~A}, 6 \mathrm{~B}, 2 \mathrm{KA}$, and $2 \mathrm{~KB})$ had to be excluded from the trial ; five were found to have a pre-vaccination antibody titre of 0.25 unit or more, indicative of a previous attack of measles, two did not complete the schedule because of illness, and four had removed from the district. There remained 26 children on schedule A, 24 on schedule B, 24 on schedule KA, and 23 on schedule KB. As will be seen from the Tables a few of these children were excluded from the final analysis, since for various reasons complete records were not obtained. Complete records following the dose of killed vaccine were available for almost all the children originally allocated to the $\mathrm{KA}$ or $\mathrm{KB}$ schedule. Of the 97 children, 52 were boys and 45 girls; one was aged 9 months and five had reached an age of 19 months or more by the time they were given the live vaccine. As in the study in general practice, these children outside the age-range 10 to 18 months have been retained in the analyses.

Highest Recorded Temperatures Seven to Ten Days After Vaccination.-Table II shows the highest recorded evening temperature during the period seven to ten days after vaccination for the children on the four vaccination schedules. "Control" information is provided by the observations following the dose of killed vaccine in those allocated to the $\mathrm{KA}$ anc $\mathrm{KB}$ schedules combined. A temperature of $103^{\circ} \mathrm{F}$. $\left(39.4^{\circ} \mathrm{C}\right.$. or more occurred in $16 \%$ of those given vaccine $A$ alone, ir. $8 \%$ of those given vaccine $\mathrm{B}$ alone, in $4 \%$ and $0 \%$ of those on the $\mathrm{KA}$ and $\mathrm{KB}$ schedules respectively, and in $2 \%$ after the killed vaccine.

TABLE II.-Highest Recorded Evening Temperature on Days 7 to 10 After Vaccination: Day-Nurseries Study

\begin{tabular}{|c|c|c|c|c|c|c|c|c|c|c|c|c|c|}
\hline \multirow{3}{*}{$\begin{array}{l}\text { Vaccina- } \\
\text { tion } \\
\text { Schedule }\end{array}$} & \multirow{3}{*}{\begin{tabular}{|c|} 
No. of \\
Children \\
with \\
Com- \\
plete \\
Records
\end{tabular}} & \multicolumn{12}{|c|}{ Highest Recorded Evening Temperature $\left({ }^{\circ}\right.$ F.) } \\
\hline & & \multicolumn{2}{|c|}{$<100$} & \multicolumn{2}{|c|}{$100-$} & \multicolumn{2}{|c|}{$101-$} & \multicolumn{2}{|c|}{$102-$} & \multicolumn{2}{|c|}{ 103- } & \multicolumn{2}{|c|}{$\begin{array}{l}104- \\
104 \cdot 9\end{array}$} \\
\hline & & No. & $\%$ & No. & $\%$ & No. & $\%$ & No. & $\%$ & No. & $\%$ & No. & $\%$ \\
\hline \multirow{4}{*}{$\begin{array}{c}\mathrm{A} \\
\mathrm{B} \\
\mathrm{KA} \\
\mathrm{KB} \\
\text { Control (fol- } \\
\text { lowing K) }\end{array}$} & 24 & 3 & 12 & $\begin{array}{l}3 \\
7\end{array}$ & 12 & 6 & 25 & 8 & 33 & 1 & 4 & 3 & 12 \\
\hline & $\begin{array}{l}233 \\
23\end{array}$ & 15 & $\begin{array}{l}43 \\
65 \\
50\end{array}$ & $\begin{array}{l}7 \\
6 \\
7\end{array}$ & $\begin{array}{l}30 \\
26\end{array}$ & $\begin{array}{l}4 \\
1\end{array}$ & 4 & $\begin{array}{l}0 \\
0\end{array}$ & 0 & 1 & 4 & $\begin{array}{l}1 \\
0\end{array}$ & 6 \\
\hline & & 30 & 67 & & & & & & & 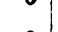 & & & \\
\hline & 48 & 32 & 01 & 11 & 23 & 3 & 6 & 1 & 2 & 0 & 0 & 1 & 2 \\
\hline
\end{tabular}

Other Symptoms.-Comparisons similar to those for th highest recorded temperature have been made for malaise, rash and upper respiratory symptoms (Table III). Those on schedul A show higher proportions affected by each of the three classe of symptoms than those on schedules $\mathrm{B}, \mathrm{KA}$, or $\mathrm{KB}$, or thost observed following their dose of killed vaccine.

TABLE III.-Number of Children With Symptoms of Various Kinds or Days 7 to 10 After Vaccination: Day-Nurseriss Study

\begin{tabular}{|c|c|c|c|c|c|c|c|}
\hline \multirow{2}{*}{$\begin{array}{l}\text { Vaccination } \\
\text { Schedule }\end{array}$} & \multirow{2}{*}{$\begin{array}{l}\text { No. of Chil- } \\
\text { dren With } \\
\text { Complete } \\
\text { Records }\end{array}$} & \multicolumn{2}{|c|}{ Malaise } & \multicolumn{2}{|c|}{ Rash } & \multicolumn{2}{|c|}{$\begin{array}{c}\text { Upper } \\
\text { Respiratory }\end{array}$} \\
\hline & & No. & $\%$ & No. & $\%$ & No. & $\%$ \\
\hline $\begin{array}{c}\mathrm{A} \\
\mathrm{B} \\
\mathrm{KA} \\
\mathrm{KB} \\
\text { Control (following K) }\end{array}$ & $\begin{array}{l}26 \\
23 \\
22 \\
22 \\
40\end{array}$ & $\begin{array}{r}20 \\
8 \\
5 \\
5 \\
18\end{array}$ & $\begin{array}{l}77 \\
35 \\
23 \\
23 \\
45\end{array}$ & $\begin{array}{l}9 \\
3 \\
0 \\
2 \\
2\end{array}$ & $\begin{array}{r}35 \\
13 \\
0 \\
9 \\
5\end{array}$ & $\begin{array}{r}18 \\
7 \\
4 \\
8 \\
12\end{array}$ & $\begin{array}{l}69 \\
30 \\
18 \\
36 \\
30\end{array}$ \\
\hline
\end{tabular}

General Assessment of Disturbance in the Child.-The day nursery staff assessed any upset or disturbance in the child sever to ten days after each dose of vaccine as "mild " or " trouble. some." Most of the 97 children had no such upset. Fouchildren had an upset classed as troublesome following vaccini A given alone, one after vaccine $B$ alone, and two each after schedules $\mathrm{KA}$ and $\mathrm{KB}$.

\section{Post-vaccination Reactions in the Two Studies Combined}

The sequelae of vaccination in the two studies have been combined in Tables IV and V. (It will be noted that the corresponding findings for the general-practitioners study alone may be determined by subtracting the numbers in Tables II and II] from those in Tables IV and V respectively.) Tables IV and V contain no information about the controls because the observa. tions made on them in the two parts of the trial differed in character and so cannot be combined. It may, however, be concluded from the comparisons in the separate studies that neither of the live vaccines, if preceded by a dose of killed vaccine, leads to reactions which are attributable to vaccination. The findings on temperatures and symptoms with the KA and KB schedules may therefore be regarded as typical of the experience of unvaccinated children in this young age-group for this time of year (January-April), and the findings for vaccination schedules A and B may be compared with this as a "control."

Highest Recorded Evening Temperatures Seven to Ten Days After Vaccination.-Table IV shows, for all children, the highest recorded early evening temperature between seven and ten days after vaccination with each of the four schedules. Of the children on schedule A, $16 \%$ showed a temperature of $103^{\circ} \mathrm{F}$. 
$\left(39.4^{\circ}\right.$ C.) or more, compared with $8 \%$ on schedule B and $2 \%$ each on schedules $\mathrm{KA}$ and $\mathrm{KB}$. Temperatures of $101^{\circ} \mathrm{F}$. $\left(38.3^{\circ}\right.$ C.) or more occurred in $53 \%, 36 \%, 7 \%$, and $11 \%$ of those on the four schedules respectively.

TABLE IV.-Htghest Recorded Evening Temperature on Days 7 to 10 After Vaccination: Both Studies Combined

\begin{tabular}{|c|c|c|c|c|c|c|c|c|c|c|c|c|c|}
\hline \multirow{3}{*}{$\begin{array}{l}\text { Vaccina- } \\
\text { tion } \\
\text { Schedule }\end{array}$} & \multirow{3}{*}{$\begin{array}{l}\text { No. of } \\
\text { Children } \\
\text { with } \\
\text { Complete } \\
\text { Records }\end{array}$} & \multicolumn{12}{|c|}{ Highest Recorded Evening Temperature $\left({ }^{\circ}\right.$ F. $)$} \\
\hline & & \multicolumn{2}{|c|}{$<100$} & \multicolumn{2}{|c|}{$100-$} & \multicolumn{2}{|c|}{$101-$} & \multicolumn{2}{|c|}{$102-$} & \multicolumn{2}{|c|}{$103-$} & \multicolumn{2}{|c|}{$\begin{array}{l}104- \\
104.9\end{array}$} \\
\hline & & No. & $\%$ & No. & $\%$ & No. & $\%$ & No. & $\%$ & No. & $\%$ & No. & $\%$ \\
\hline $\begin{array}{l}\mathbf{A} \\
\mathbf{B} \\
\mathbf{K A} \\
\mathbf{K B}\end{array}$ & $\begin{array}{l}79 \\
76 \\
62 \\
66\end{array}$ & $\begin{array}{l}17 \\
34 \\
38 \\
47\end{array}$ & $\begin{array}{l}22 \\
45 \\
61 \\
71\end{array}$ & \begin{tabular}{l|}
20 \\
14 \\
20 \\
12
\end{tabular} & $\begin{array}{l}25 \\
18 \\
32 \\
18\end{array}$ & $\begin{array}{r}17 \\
11 \\
1 \\
4\end{array}$ & $\begin{array}{r}22 \\
14 \\
2 \\
6\end{array}$ & $\begin{array}{r}12 \\
11 \\
2 \\
2\end{array}$ & $\begin{array}{r}15 \\
14 \\
3 \\
3\end{array}$ & $\begin{array}{l}8 \\
3 \\
1 \\
1\end{array}$ & $\begin{array}{r}10 \\
4 \\
2 \\
2\end{array}$ & $\begin{array}{l}5 \\
3 \\
0 \\
0\end{array}$ & $\begin{array}{l}6 \\
4 \\
0 \\
0\end{array}$ \\
\hline
\end{tabular}

Other Symptoms.-The corresponding information on rash, nalaise, and upper respiratory symptoms for the whole trial (Table V) indicates that these symptoms occurred more often in those given vaccine $\mathrm{A}$ alone, and possibly more often also in those given vaccine $B$ alone, than in those on the $K A$ or $K B$ schedules in whom the symptoms did not appear to be attributable to the vaccination.

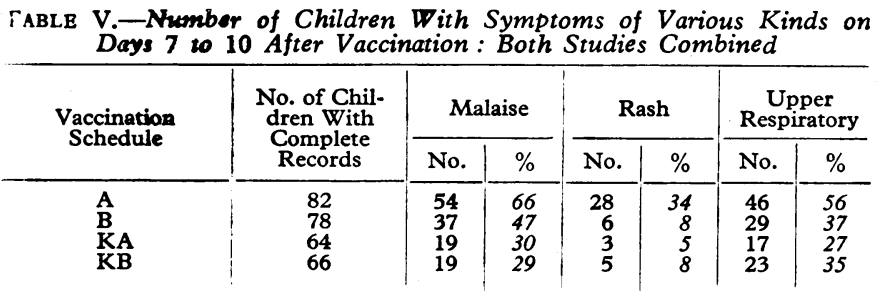

\section{"Troublesome" Episodes}

In only 6 of the 21 episodes described as "troublesome" Jid the temperature rise to $103^{\circ} \mathrm{F}$. $\left(39.4^{\circ} \mathrm{C}\right.$.) or more. Only three of the episodes were of sufficient clinical interest to warrant special mention and none of them was unequivocally attributable to the vaccination. Two were from the generalpractitioners study and one from a day nursery. The first child schedule A, aged 13 months) had had a mild respiratory infecion seven to ten days before the dose of vaccine. This had :esponded to oral antibiotics and she was apparently well, with a normal temperature but with a slight cough at the time the live vaccine was given. Seven days later, however, her temperature rose to $103^{\circ} \mathrm{F}$. $\left(39.4^{\circ} \mathrm{C}\right.$.) (rectal) and she was admitted to hospital with acute bronchitis and general lymphadenopathy. The illness responded to antibiotics and she was discharged three lays later. This incident indicates that a period longer than a week should be allowed between any illness and vaccination. In he second child (schedule KA, aged 14 months) generalized irticaria developed on the fifth day after the live vaccine. This asted for 10 days and was not accompanied by fever or any other symptoms; there was no history of previous attacks. A third child (schedule KB, aged 13 months) had a macular srythematous rash on his back and limbs, with general lymphadenopathy and a temperature of 101 to $102^{\circ} \mathrm{F}$. (38.3 to $38.9^{\circ}$ C.) on the seventh day after the live vaccine. He was admitted to hospital, where glandular fever was diagnosed from the clinical condition and the white-cell count, although two PaulBunnell tests were negative. The child made an uneventful recovery in 10 days. This case is mentioned only because of the appearance of symptoms around the seventh day after live vaccine.

There were three other hospital admissions for acute illness among the children in the day nurseries, all following doses of the killed vaccine, and none of them attributable to the vaccine. These were a case of Sonne dysentery, a staphylococcal submandibular abscess, and a haemolytic streptococcal tonsillitis in a child who was admitted for failure to gain weight.

\section{Serological Tests}

Sera.-Blood samples of 1 to $2 \mathrm{ml}$. were obtained from the subjects either by venepuncture or by heel-prick. They were centrifuged before pipetting off the sera, which were then treated with kaolin and adsorbed with monkey erythrocytes to remove non-specific haemagglutinins (Rosen, 1960). These treated sera were stored at $-20^{\circ} \mathrm{C}$. until tested, and for each subject the sera taken before and after immunization were titrated in the same test.

Antigen.-Antigen for the haemagglutination-inhibition test was prepared in HeLa tissue cultures inoculated with the Philadelphia-26 strain of measles virus and incubated at $37^{\circ} \mathrm{C}$. for 14 to 17 days. Either a harvest of the culture fluid or an extract from disrupted cells was used as antigen, and similar results were obtained with the antigen prepared by both methods.

Haemagglutination-inhibition Test.-All sera were titrated by the haemagglutination-inhibition test as described by Rosen (1961). The treated sera were tested for 0.25 unit per ml. or more, using twofold dilutions. To each $0.2 \mathrm{ml}$. of serum dilution $0.2 \mathrm{ml}$. of antigen was added to give a final concentration of four minimal haemagglutinating doses; the mixtures were held at room temperature (16 to $20^{\circ}$ C.) for one hour before adding $0.2 \mathrm{ml}$. of $1 \%$ rhesus monkey erythrocytes and incubating at $37^{\circ} \mathrm{C}$. for one hour. After this time the titres were recorded as the highest initial dilution of serum showing inhibition of haemagglutination ( $50 \%$ end-point), from which the number of units of antibody in the undiluted serum was calculated. Antibody titres are given in international units as the international reference preparation for anti-measles serum to which a unitage has been assigned has now been established by the World Health Organization and is distributed by the State Serum Institute, Copenhagen. In these tests a titre of 1 unit was approximately equivalent to a titre of $1: 64$. It has been shown, however, that this relationship cannot be relied upon with all haemagglutinating systems, and it is therefore recommended that in future the standard serum or an equivalent working standard should always be included when titrating sera. It is only in this way that a meaningful comparison can be made of the results from different workers.

Results of Serological Tests.-Only those children with no antibody in their pre-vaccination serum-that is, titre less than 0.25 unit-were considered to be non-immune to measles and were included in the analysis. The titres of the post-vaccination sera in the four schedules are shown in Table VI for the whole investigation. A titre of 0.5 unit or more antibody was obtained in $99 \%$ of the children on schedule A, $96 \%$ on schedule B,

TABLE VI.-Haemagglutination-inhibition Antibody Titres : Both Studies Combined

\begin{tabular}{|c|c|c|c|c|c|c|c|c|c|c|c|c|c|c|c|c|c|c|}
\hline \multirow{3}{*}{$\begin{array}{l}\text { Vaccination } \\
\text { Schedule }\end{array}$} & \multirow{3}{*}{$\begin{array}{l}\text { No. of } \\
\text { Children } \\
\text { with } \\
\text { Complete } \\
\text { Records }\end{array}$} & \multicolumn{16}{|c|}{ Post-vaccination Antibody Titres (Units $/ \mathrm{ml}$.) } & \multirow{3}{*}{$\begin{array}{c}\text { Geometric } \\
\text { Mean } \\
\text { Titre } \\
\text { (Units/ml.) }\end{array}$} \\
\hline & & \multicolumn{2}{|c|}{$<0.5$} & \multicolumn{2}{|c|}{$0.5-1$} & \multicolumn{2}{|c|}{$1-2$} & \multicolumn{2}{|c|}{$2-4$} & \multicolumn{2}{|c|}{ 4-8 } & \multicolumn{2}{|c|}{$8-16$} & \multicolumn{2}{|c|}{$16-32$} & \multicolumn{2}{|c|}{$>32$} & \\
\hline & & No. & $\%$ & No. & $\%$ & No. & $\%$ & No. & $\%$ & No. & $\%$ & No. & $\%$ & No. & $\%$ & No. & $\%$ & \\
\hline $\begin{array}{l}\mathrm{A} \\
\mathrm{B} \\
\mathrm{KA} \\
\mathbf{K B}\end{array}$ & $\begin{array}{l}77 \\
75 \\
59 \\
64\end{array}$ & $\begin{array}{l}1 \\
3 \\
1 \\
3\end{array}$ & $\begin{array}{l}1 \\
4 \\
2 \\
5\end{array}$ & $\begin{array}{l}1 \\
2 \\
3 \\
5\end{array}$ & $\begin{array}{l}1 \\
3 \\
5 \\
8\end{array}$ & $\begin{array}{r}2 \\
5 \\
14 \\
11\end{array}$ & $\begin{array}{r}3 \\
7 \\
24 \\
17\end{array}$ & $\begin{array}{l}16 \\
22 \\
13 \\
16\end{array}$ & $\begin{array}{l}21 \\
29 \\
22 \\
25\end{array}$ & $\begin{array}{l}20 \\
17 \\
16 \\
18\end{array}$ & $\begin{array}{l}26 \\
23 \\
27 \\
28\end{array}$ & $\begin{array}{l}23 \\
20 \\
10 \\
10\end{array}$ & $\begin{array}{l}30 \\
27 \\
17 \\
16\end{array}$ & $\begin{array}{r}11 \\
5 \\
1 \\
0\end{array}$ & $\begin{array}{r}14 \\
7 \\
2 \\
0\end{array}$ & $\begin{array}{l}3 \\
1 \\
1 \\
1\end{array}$ & $\begin{array}{l}4 \\
1 \\
2 \\
2\end{array}$ & $\begin{array}{l}5 \cdot 3 \\
3 \cdot 4 \\
2 \cdot 5 \\
2 \cdot 3\end{array}$ \\
\hline
\end{tabular}


$98 \%$ on schedule $\mathrm{KA}$, and $95 \%$ on schedule $\mathrm{KB}$. While the antibody conversion rates are similar in all groups, there were differences in the geometric mean titres between the vaccination schedules-namely, 5.3 units for schedule A, 3.4 for schedule B, 2.5 for schedule KA, and 2.3 for schedule KB. Neither the difference between schedule $A$ and $B$ nor that between schedule $\mathrm{KA}$ and $\mathrm{KB}$ was statistically significant, but the difference between the schedules with and without killed vaccine was highly significant $(P<0.001)$.

\section{Association Between Vaccination Results and Post-vaccination Antibody Titres}

The absence of reactions attributable to vaccination in those children on schedules $\mathrm{KA}$ and $\mathrm{KB}$, and the lower average postvaccination titres with these schedules, raise the possibility that there may be some association between the intensity of a vaccination reaction and the level of post-vaccination antibody titre attained. This possibility was studied among those given live vaccine alone. The mean post-vaccination antibody titres were tabulated for the schedules A and B combined according to the highest recorded evening temperatures and the presence or absence of symptoms of malaise (Table VII). There is some suggestion that the mean titres were higher in those with temperatures of $101^{\circ} \mathrm{F}$. $\left(38.3^{\circ} \mathrm{C}\right.$.) or more, as well as in those with malaise, than in those with lower temperatures or without malaise, but the association does not appear to be particularly strong. It must be remembered, however, that any association will have been obscured to some extent in this tabulation by the fact that a proportion of the temperature rises and symptoms of malaise were not attributable to the vaccination.

\section{Discussion}

This trial of measles vaccines was made in children aged about 10 to 18 months, who were thus at the beginning of the period of susceptibility to measles. Since it was concerned only with the immediate clinical and serological responses to vaccination it provides information on the acceptability of different vaccination schedules in this age-group and on their potential efficacy but not, so far, on their ability to prevent the disease. It is intended to follow these children and to record their experience of measles, but a decisive answer on long-term protection is unlikely with these small numbers. A further and larger trial of the long-term protective efficacy of measles vaccines in this age-group is now being undertaken.

During the observation period there was no difference in the frequency and distribution of constitutional upsets and symptomatology between the unvaccinated children and those in whom a dose of live vaccine had been preceded by the killed vaccine. The frequency of these episodes was, however, higher in those receiving a dose of live vaccine alone, particularly those having vaccine $\mathrm{A}$ alone, and there was a concentration of malaise, rashes, and upper respiratory symptoms in the period seven to ten days after vaccination, usually accompanied by an evening temperature rising to $101^{\circ} \mathrm{F}$. $\left(38.3^{\circ} \mathrm{C}\right.$.) or more. It is concluded that some upsets attributable to the vaccine occurred at this interval after giving live vaccine, but, in view of the high incidence of coincidental minor illnesses and the relatively small numbers of children observed, it is not possible to make useful estimates of the frequency of the constitutional upsets due to live vaccine given alone. None of the reactions were clinically serious and they did not appear to give contraindication to the use of these live vaccines alone.

For the age-group 10 to 18 months it may be concluded that all four vaccination schedules were acceptable and practical. Although some children had a febrile reaction and occasionally a rectal temperature as high as $104^{\circ} \mathrm{F}$. $\left(40^{\circ} \mathrm{C}\right.$.), the fever was transitory and apparently caused little distress. Moreover, although upper respiratory symptoms and malaise were on the whole commoner in the groups receiving live vaccine alone than in those in which an injection of killed vaccine was given first, in general the differences in the reactions of the children in the different groups were not great.

Between $95 \%$ and $99 \%$ of the children on each of the four vaccination schedules showed a post-vaccination antibody titre of 0.5 unit or more, which may be regarded as a satisfactory immediate serological response. There thus appeared to be nothing to choose between the four schedules in this respect. The mean post-vaccination titres, however, varied, being rather greater after vaccine $A$ than after vaccine $B$. Moreover, the mean titres were definitely greater after a single injection of a live vaccine than those obtained when the dose of live vaccine was preceded by a single injection of killed vaccine. It is not known whether these antibody responses are likely to be relevant to long-term protection; this is an added reason for studying the protection from these schedules in this age-group and doing so through more than one epidemic period.

The finding that a smaller mean antibody response followed the two-dose schedule is of some interest. The explanation may lie in the relatively large dose of killed vaccine $(1 \mathrm{ml}$.) that preceded the live vaccine or the relatively short interval (four to six weeks) between the two doses, and further work is necessary in order to elucidate this finding.

It must be emphasized that these conclusions relate only to the particular vaccines tested and only to children aged about 10 to 18 months. Attenuated vaccines may well become available which will give adequate antibody responses from a single dose without any detectable clinical reactions. However, a further criterion by which any vaccination schedule must be judged is the extent and duration of its protective efficacy against measles; and this information, by its very nature, cannot be obtained quickly.

\section{Summary}

Two live attenuated measles vaccines given either alone or preceded by a single dose of inactivated measles vaccine were investigated in children 10 to 18 months old. In all, 299 children were divided between the four schedules, and the vaccination reactions and antibody responses were followed.

The children given live vaccine alone showed a greater incidence of febrile reactions than those given live vaccine after the inactivated vaccine. Information on rashes, malaise, and upper respiratory symptoms also showed that these occurred more often when live vaccine was given alone, although none of the children had more than a minor upset attributable to the vaccine and all vaccine schedules were considered to be acceptable.

Between $95 \%$ and $99 \%$ of the children in each schedule gave a post-vaccination measles antibody titre of 0.5 unit or more.

TABLE VII-Number of Children and Geometric Mean Titre (GMT) According to Hịghest Recorded Evening Temperature and Symptoms of Malaise on Days 7 to 10 After Vaccination: Schedules $A$ and B Combined

\begin{tabular}{|c|c|c|c|c|c|c|c|c|c|c|c|c|c|c|c|c|c|}
\hline & & & & \multirow{2}{*}{\multicolumn{2}{|c|}{$\begin{array}{c}\text { No. of Children } \\
\text { with Complete } \\
\text { Records }\end{array}$}} & \multicolumn{12}{|c|}{ Highest Recorded Evening Temperature ( $\left.{ }^{\circ} \mathrm{F}.\right)$} \\
\hline & & & & & & \multicolumn{2}{|c|}{$<100$} & \multicolumn{2}{|c|}{100} & \multicolumn{2}{|c|}{$101-$} & \multicolumn{2}{|c|}{$102-$} & \multicolumn{2}{|c|}{$103-$} & \multicolumn{2}{|c|}{$104-104 \cdot 9$} \\
\hline & & & & No. & GMT & No. & GMT & No. & GMT & No. & GMT & No. & GMT & No. & GMT & No. & GMT \\
\hline $\begin{array}{l}\text { Malaise } \\
\text { No malaise }\end{array}$ & $\because$. & $\begin{array}{l}\cdots \\
\cdots\end{array}$ & 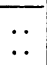 & $\begin{array}{l}82 \\
63\end{array}$ & $\begin{array}{l}5 \cdot 2 \\
3 \cdot 3\end{array}$ & $\begin{array}{l}15 \\
32\end{array}$ & $\begin{array}{l}3 \cdot 3 \\
3 \cdot 3\end{array}$ & $\begin{array}{l}12 \\
22\end{array}$ & $\begin{array}{l}4.5 \\
2 \cdot 3\end{array}$ & $\begin{array}{r}22 \\
4\end{array}$ & $\begin{array}{r}4 \cdot 8 \\
13 \cdot 5\end{array}$ & $\begin{array}{r}15 \\
5\end{array}$ & $\begin{array}{l}8 \cdot 0 \\
5 \cdot 3\end{array}$ & $\begin{array}{r}11 \\
0\end{array}$ & 5.5 & $\begin{array}{l}7 \\
0\end{array}$ & 8.0 \\
\hline
\end{tabular}


The children given live vaccine alone, however, gave significantly higher antibody responses than when live vaccine was preceded by a single dose of inactivated vaccine.

This preliminary trial has not given any information on protection against the disease ; this is the aim of a second study now in progress.

We are grateful to the following general practitioners for finding time in their busy practices to take part in the study:

Dr. D. M. Baker (Northwood), Dr. A. P. Barter (Bridport), Dr. S. Bedford (Grimsby), Dr. D. Budge (Leighton Buzzard), Dr. S. Carne (London $W .12$ ), Dr. G. Edelsten (Sutton Scotney), Dr. E. Gancz (Dartford), Dr. M. Goodman (Liverpool 6), Dr. R. P. C. Handfield-Jones (Haddenham), Dr. D. W. Hendry (Fife), Dr. E. R. Herst (Woodford Green), Dr. M. E. Holzer (London W.1), Dr. P. Hopkins (London N.W.3), Dr. S. G. Jeffs (Manchester), Dr. R. D. Jones (Godalming), Dr. H. Kidd (Buxton), Dr. K. Lane (London W.C.1), Dr. A. B. Lowther (Porthcawl), Dr. J. K. H. McCullough (Kings Norton), Dr. G. MacNaughton (Edinburgh 4), Dr. R. L. Meyrick (London S.E.6), Dr. J. H. Owen (Porthcawl), Dr. A. Wilson Robertson (Leven, Fifeshire), Dr. Watson Rogers (Sherborne), Dr. H. S. Samuel (Theale), Dr. M. Schapira (Keighley), Dr. F. S. Shepherd (Southall), Dr. S. J. Silvey (Coombe Dingle, Bristol 9), Dr. E. Sklar (London N.W.10), Dr. G. R. Staley (Hull), Dr. J. M. Stuart (Coleshill), Dr. M. T. Sweetnam (Stoke-on-Trent), Dr. B. A. Thompson (Chester), Dr. M. K. Thompson (Addiscombe), Dr. T. J. C. Warriner (Chessington), Dr. G. I. Watson (Guildford), Dr. J. McA. Williams (Hartington, nr. Buxton), Dr. W. O. Williams (Swansea).

We are also grateful to Dr. M. T. Paterson, Dr. S. King, and Dr. W. H. S. Wallace, of London County Council Divisions 2, 4, and 8 , and to the matrons and nursing staff of the day nurseries in these divisions for their help.

Our thanks are also due to Dr. J. A. Scott (since deceased), who at the time of the trial was Medical Officer of Health for the London
County Council, and to Dr. Ian Taylor, of the London County Council Department of Public Health.

Finally we would like to acknowledge the assistance of Dr. P. Benson, who obtained blood samples from the children in the day nurseries.

We are pleased to add our thanks to Glaxo Laboratories, Pfizer Ltd., and Wellcome Research Laboratories for the vaccines which they supplied free of charge.

\section{RBFERENCES}

Andelman, S. L., Schwarz, A., Andelman, M. B., and Zackler, J. (1963). 7. Amer. med. Ass., 184, 721.

Benson, P. F., Butler, N. R., Goffe, A. P., Knight, G. J., Laurence, G. D., Miller, C. L., and Pollock, T.' M. (1964). Brit. med. F., 2,851 .

Carter, C. H., Conway, T. J., Cornfeld, D., Iezonni, D. G., Kempe C. H., Moscovici, C., Rauh, L. W., Vignec, A. J., and Warren, J. (1962). F. Amer. med. Ass., 179, 848.

Enders, J. F. Katz, S. L., Milovanović, M. V., and Holloway, Ann

(1960). New Engl. F. Med., 263, 153.

- and Peebles, T. C. (1954). Proc. Soc. exp. Biol. (N.Y.), 86, 277

ulginit, V. A., Leland, O. S., and Kempe, C. H. (1963). Amer. Y. Dis. Child., 105, 5.

Guinee, V. F., et al. (1963). Amer. f. publ. Hlth, 53, 645.

Hendrickse, R. G., Montefiore, D., Sherman, P. M., and van der Wall, H. M. (1964). Brit. med. F., 1, 470.

Katz, S. L., and Enders, J. F. (1959). Amer. 7. Dis. Child., 98, 605. Milovanović, M. V., and Enders, J. F. (1958). Proc. Soc. exp.

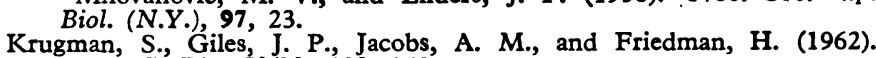
Amer. f. Dis. Child., 103, 353 .

Amer. F. Dis. Child., 103, 353. (1963). F. Pediat., 31, 919.

Mille Friedman, H., and Stone, S. (1965). ₹. Pediat. In press.

Miller, D. L. (1964). Brit. med. F., 2, 75 . exp. Biol. (N.Y.), 95, 120 .

Moncrieft, A., and Hussey, B. J. (1948). Brit. med. F., 2, 972.

Rosen, L. (1960). Amer. F. Hyg., 71, 120.

Rosen, (1961). Virology, 13, 139.

Schwarz, A. J. F. (1962). Amer. F. Dis. Child., 103, 386. Schwarz, A. J. F. (1962). Amer. F. Dis. Child., 103, 386. Halenda, R.,

and Goldner, H. (1961). Nerw Engl. f. Med., 265, 507. $103,418$.

Warren, J., and Gallian, M. J. (1962). Amer. J. Dis. Child., 103, 418.
W.H.O. Expert Committee on Biological Standardization (1964). Wld Hith Org. tech. rep. Ser., No. 293.

\title{
A Laser Ophthalmoscope for Retinal Phototherapy
}

\author{
H. VERNON INGRAM,* O.B.E., T.D., M.B., F.R.C.S., D.o.M.S. ; NEIL MANSON,* M.B., B.S., D.o. ; \\ DESMOND SMART, $\dagger$ M.SC.
}

[With Special Plate]

Brit. med. F., 1965, 1, 823-827

The rapid advancement of maser and laser technology has provided medical science, and in particular ophthalmology, with a therapeutic coherent light source.

Maser and laser stand for microwave and light amplification by the stimulated emission of radiation. The maser works in the centimetre or submillimetre microwave region, and the laser in the near optical (almost to ultra-violet) frequency range. Since the media of the eye transmit the radiations in the range from 4,000 to $9,000 \AA$ (Fig. I) the energy from a low-power laser working in this range can be focused on the retina without producing any molecular disturbance of the transparent media of the eye.

Stimulated emission from an atomic assembly was first suggested by Einstein in 1917 from considerations of thermodynamic equilibrium. In 1953 and subsequently, the theoretical possibilities of microwave amplification were further considered by Weber (1953), Townes, Basov, and Prokhorov. Gordon,

\footnotetext{
* Department of Ophthalmology, University of Newcastle upon Tyne and Royal Victoria Infirmary, Newcastle upon Tyne.

t Head of Applied Physics Section, International Research and Development Company Limited, Fossway, Newcastle upon Tyne.
}

Zeiger, and Townes (1954) produced an ammonia gas maser. The investigation of solid-state masers by Combrisson, Honig, and Townes (1956) resulted in the production of some discontinuously operating devices. Bloembergen (1956) postulated the continuous emission maser, and Scovil, Feher, and Seidel

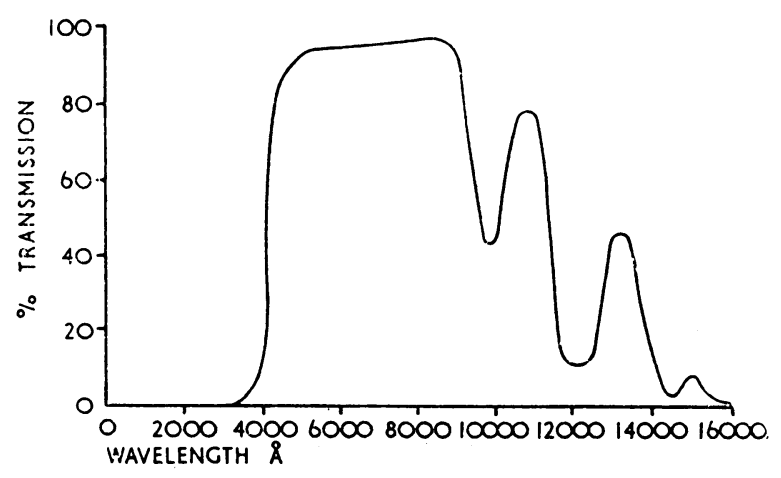

FIG. I.-Spectral transmission curve of the refractive media of the human eye. 